Baszyński A., X-inefficiency of commercial banks in the countries of Central, Eastern and South-Eastern Europe, „Ekonomia i Prawo. Economics and Law.”, Polszakiewicz B., Boehlke J. (ed.), Vol. 13, No. 2/2014, pp. 259-274. DOI: http://dx.doi.org/10.12775/EiP.2014.019.

\title{
X-INEFFICIENCY OF COMMERCIAL BANKS IN THE COUNTRIES OF CENTRAL, EASTERN AND SOUTH-EASTERN EUROPE ${ }^{\diamond}$
}

\author{
SUMMARY
}

It is sometimes attempted to measure the productive efficiency of the banking sector in a direct way. This approach uses the concept of $\mathrm{X}$-inefficiency introduced by H. Leibenstein. In general, the X-inefficiency is the difference between efficient behaviour of the supplier and his real behaviour. One of the main reasons for the existence of $\mathrm{X}$-inefficiency is the lack of competitive pressure, due to which the maximization of profit ceases to be a precondition of market survival. This may lead to wasting resources. $\mathrm{X}$-inefficiency exists when the cost of the production of a given good by the supplier is bigger than the lowest possible cost of producing this good.

The aim of the article is to specify the level of competition in the banking services markets in the countries of Central, Eastern and South-Eastern Europe (CE$\mathrm{SEE}$ ) with the use of the cost inefficiency of banks. For this purpose data concerning the cost-to-income ratio $(C / I)$ in 2005-2011 are used. The data come from the BankScope database. In the study the distance from the pattern method was applied. This article adopts the hypothesis that the level of efficiency of banks is far from the pattern one and inefficiency indicates the imperfectly competitive market structure.

* Adam Baszyński, Poznań University of Economics, Faculty of Economics, Department of Macroeconomics and History of Economic Thought, Al. Niepodległości 10, 61-875 Poznań, phone: +48 618543 014, e-mail: a.baszynski@ue.poznan.pl.

$\checkmark$ The article was financed from the resources of the National Science Centre (NCN) granted on the basis of decision number DEC-2011/01/B/HS4/00802. 
Keywords: cost efficiency, competition, bank

JEL Classification: D24, L13

\section{INTRODUCTION}

The interest in measuring competition in the banking services market has grown over the recent years. Traditionally, banks used to be perceived as public trust institutions and banking sectors - as free of competition. However, the progressive liberalization and deregulation have turned modern banking sectors into highly competitive markets. In the light of the experiences of the global financial crisis, the debate about competition, efficiency and stability of banking sectors revived.

The traditional perspective in the debate of efficiency versus stability assumed the "either-or" approach to the relation between the efficiency and the stability of the banking sector. The rationale behind this approach was as follows: the increase (decrease) in competition causes the decrease (increase) of market power; competition improves the efficiency of the sector, which means that it facilitates economic growth, but market power is crucial to ensure the stability of the sector, which excludes competition. Contemporarily, the relation between the level of competition and the level of efficiency and stability does not seem so simple anymore. In the relevant literature no consensus can be found as to which of the structures of the banking services market ensures the optimum combination of efficiency and stability.

This article adopts the hypothesis that the level of efficiency of banks is far from the pattern one and inefficiency indicates the imperfectly competitive market structure.

\section{THEORETICAL SOLUTIONS}

The numerous methods used to measure competition in a given industry may be generally divided into structural and non-structural. The first group of methods is based on the assumption that the behaviour of competing suppliers can be inferred on the basis of market concentration, i.e., information about the distribution of the market shares of individual suppliers and on their number. The other group of methods takes into account factors other than concentration which may have an impact on competition. These include barriers to entry and asymmetric information. Structural methods aim at measuring competition in an indirect way - by concentration ratios, which 
we refer to as the structure-conduct-performance paradigm (SCPP) ${ }^{1}$. Nonstructural methods are used to measure competition in a direct way - by estimating the monopolistic power of suppliers (e.g. a surcharge on the price) ${ }^{2}$.

In relation to the banking sector the most common ways to measure competition are: among the structural methods - the market value ratio $\mathrm{k}$ of the largest suppliers in the market $\left(C R_{k}\right)$ and the Herfindahl-Hirschman Index (HHI), and among the non-structural methods - the $H$ statistics estimated on the basis of the Panzar-Rosse model (P-R). The results of studies based on structural methods indicate a relatively high level of concentration of banking sectors in European transition countries ${ }^{3}$. At the same time, the results of studies conducted on the basis of non-structural methods suggest that the dominant competition structure of the banking services market in this area is monopolistic competition ${ }^{4}$. Although the long term balance

1 E.S. Mason, Price and Production Policies of Large-scale Enterprises, „American Economic Review", Vol. 29, No. 1/1939; J.S. Bain, Barriers to New Competition: Their Character and Consequences in Manufacturing Industries, Harvard University Press, Cambridge 1956.

2 A.P. Lerner, The Concept of Monopoly and the Measurement of Monopoly Power, „Review of Economic Studies", Vol. 1, No. 3/1934.

${ }^{3}$ ECB, Statistical Data Warehouse. Structural Financial Indicators, http://sdw.ecb.europa.eu (19.03.2013); D. Holló, M. Nagy, Bank Efficiency in the Enlarged European Union, MNB Working Papers, No. 3/2006, MNB, Budapest 2006, p. 18.

4 The existence of monopolistic competition in the banking services market in the CESEE countries is indicated by 83 results out of 89 estimations made for 19 CESEE countries in 14 studies: G.R. Gelos, J. Roldos, Consolidation and Market Structure in Emerging Market Banking Systems, „IMF Working Paper”, No. 186/2002, p. 19; H.S. Yildirim, G.C. Philippatos, Competition and Contestability in Central and Eastern European Banking Markets, „Managerial Finance", Vol. 33, No. 3/2007, p. 39; S. Claessens, L. Laeven, What Drives Bank Competition? Some International Evidence, "Journal of Money, Credit and Banking”, Vol. 36, No. 3/2004, p. 573; K. Drakos, P. Konstantinou, Competition and Contestability in Transition Banking: An Empirical Analysis, „South-Eastern Europe Journal of Economics”, Vol. 3, No. 2/2005, p. 202; E. Mamatzakis, C. Staikouras, N. Koutsomanoli-Fillipaki, Competition and Concentration in the Banking Sector of the South Eastern European Region, „Emerging Markets Review”, Vol. 6, No. 2/2005, p. 204; A. Mkrtchyan, The Evolution of Competition in Banking in a Transition Economy: An Application of the Panzar-Rosse Model to Armenia, „European Journal of Comparative Economics", Vol. 2, No. 1/2005, p. 75; M. Pawłowska, Competition, Concentration, Efficiency, and their Relationship in the Polish Banking Sector, „Materiały i Studia”, No. 32/2005, NBP, Warszawa 2005, p. 33-35; N. Koutsomanoli-Fillipaki, Ch. Staikouras, Competition and Concentration in the New European Banking Landscape, "European Financial Management”, Vol. 12, No. 3/2006, p. 461; S. Note, Competition in the Albanian Banking System, Bank of Albania Working Paper, Tirana 2007, p. 24; A. Utmelidze, Banking Competition: The Case of Georgia and Belarus, http://kse.org.ua/uploads/file/library/2007/utmelidze_2007.doc, p. 28 (12.06.2013); J.A. Bikker, L. Spierdijk, How Banking Competition Changed over Time?, DNB Working Papers, No. 167/2008, De Nederlndsche Bank, Amsterdam 2008, p. 25-26; D. Anzoategui, M.S. Martínez Pería, R. Rocha, Bank Competition in the Middle East and Northern Africa Region, „World 
in monopolistic competition is not a socially optimum solution ${ }^{5}$, highly concentrated banking sectors of the CESEE countries are characterized by a relatively high level of competition, higher than in mature market economies ${ }^{6}$.

In the relevant literature it is sometimes attempted to measure the productive efficiency of the banking sector in a direct way. This approach uses, among other concepts, the concept of X-inefficiency introduced by H. Leibenstein ${ }^{7}$. In general, the X-inefficiency is the difference between efficient (i.e. in accordance with the theory of economics) behaviour of the supplier and his real (i.e. observed) behaviour. One of the main reasons for the existence of $\mathrm{X}$-inefficiency is the lack of competitive pressure, due to which the maximization of profit ceases to be a precondition of market survival. This may lead to wasting resources (productive inefficiency). X-inefficiency exists when the cost of the production of a given good by the supplier is bigger than the lowest possible cost of producing this good. The relevant literature presents evidence for the X-inefficiency of $\mathrm{banks}^{8}$, although the interdependencies between competition, inefficiency and the economics of scales remain unclear ${ }^{9}$.

\section{AIMS AND METHODS}

The aim of the article is to specify the level of competition in the banking services markets in the countries of $\mathrm{CESEE}^{10}$ with the use of the cost in-

Bank Policy Research Working Paper”, No. 5363/2010, p. 19; M.D. Delis, Competitive Conditions in the Central and Eastern European Banking Systems, „Omega”, Vol. 38, No. 5/2010, p. 271; Pawłowska M., Konkurencja na polskim rynku bankowym na tle zmian strukturalnych i technologicznych - wyniki empiryczne, [in:] E. Miklaszewska (ed.), Bank na rynku finansowym. Problemy skali, efektywności i nadzoru, Oficyna a Wolters Kluwer business, Warszawa 2010, p. 379.

${ }^{5}$ Compared to the perfect competition, suppliers in the monopolistic competition produce a smaller product $Q$ and sell it at a higher price $p$.

${ }^{6}$ J.A. Bikker, L. Spierdijk, op. cit., p. 20.

7 H. Leibenstein, Allocative Efficiency vs. X-Efficiency, „American Economic Review”, Vol. 56, No. 3/1966.

${ }^{8}$ A.N. Berger, L. Mester, Inside the Black Box: What Explains Differences in the Efficiencies of Financial Institutions?, „Journal of Banking and Finance”, Vol. 21, No. 7/1997.

9 C.A. Northcott, Competition in Banking: A Review of the Literature, Bank of Canada Working Paper, No. 24/2004, Bank of Canada, Ottawa 2004, p. 11.

${ }_{10}$ The CESEE region was divided into three geographical groups: Central Europe and the Baltics (CEB); South East Europe (SEE) and Eastern Europe (EE). The CEB group includes: Croatia (HRV), Czech Republic (CZE), Estonia (EST), Lithuania (LTU), Latvia (LVA), Poland (POL), Slovakia (SVK), Slovenia (SVN) and Hungary (HUN). The SEE includes: Albania (ALB), Bosnia and Herzegovina (B\&H), Bulgaria (BGR), Montenegro (MNE), Macedonia 
efficiency of banks. For this purpose data concerning the cost-to-income ratio on the microeconomic level in 2005-2011 are used. The data come from the BankScope database ${ }^{11}$. Descriptive statistics are included in table 1 . The total number of observations is 5079 and it is about $90 \%$ of the banks operating in particular countries ${ }^{12}$.

Table 1. The weighted average of the $C / /$ ratio, the number of observations and the change in the cost efficiency

\begin{tabular}{|c|c|c|c|c|c|c|c|c|c|}
\hline \multirow{2}{*}{ Code } & \multicolumn{7}{|c|}{ Years } & \multirow{2}{*}{$\begin{array}{c}\text { Average } \\
\text { (total) }\end{array}$} & \multirow{2}{*}{ Change } \\
\hline & 2005 & 2006 & 2007 & 2008 & 2009 & 2010 & 2011 & & \\
\hline \multicolumn{10}{|c|}{ Countries } \\
\hline$A L B$ & $\begin{array}{c}60.86 \\
(5)\end{array}$ & $\begin{array}{c}65.08 \\
(7)\end{array}$ & $\begin{array}{c}48.55 \\
(8)\end{array}$ & $\begin{array}{c}49.62 \\
(7)\end{array}$ & $\begin{array}{c}49.34 \\
(9)\end{array}$ & $\begin{array}{c}49.32 \\
(11)\end{array}$ & $\begin{array}{c}47.15 \\
(9)\end{array}$ & $52.84(56)$ & imp. \\
\hline$B G R$ & $\begin{array}{c}20.84 \\
(24)\end{array}$ & $\begin{array}{c}26.52 \\
(24)\end{array}$ & $\begin{array}{c}33.44 \\
(19)\end{array}$ & $\begin{array}{c}46.89 \\
(24)\end{array}$ & $\begin{array}{c}46.70 \\
(25)\end{array}$ & $\begin{array}{c}47.80 \\
(25)\end{array}$ & $\begin{array}{c}47.81 \\
(24)\end{array}$ & 38.57 (165) & det. \\
\hline B\&H & $\begin{array}{c}63.64 \\
(18)\end{array}$ & $\begin{array}{c}62.47 \\
(17)\end{array}$ & $\begin{array}{c}61.48 \\
(20)\end{array}$ & $\begin{array}{c}69.23 \\
(20)\end{array}$ & $\begin{array}{c}64.91 \\
(20)\end{array}$ & $\begin{array}{c}65.78 \\
(23)\end{array}$ & $\begin{array}{c}63.63 \\
(22)\end{array}$ & 64.45 (140) & det. \\
\hline BLR & $\begin{array}{c}73.60 \\
\text { (9) }\end{array}$ & $\begin{array}{c}66.30 \\
(10)\end{array}$ & $\begin{array}{c}66.96 \\
(14)\end{array}$ & $\begin{array}{c}63.55 \\
(16)\end{array}$ & $\begin{array}{c}46.18 \\
(18)\end{array}$ & $\begin{array}{c}50.93 \\
(21)\end{array}$ & $\begin{array}{c}40.93 \\
(13)\end{array}$ & 58.35 (101) & imp. \\
\hline CZE & $\begin{array}{c}54.28 \\
(30)\end{array}$ & $\begin{array}{c}53.70 \\
(27)\end{array}$ & $\begin{array}{c}51.32 \\
(29)\end{array}$ & $\begin{array}{c}54.04 \\
(32)\end{array}$ & $\begin{array}{c}41.03 \\
(35)\end{array}$ & $\begin{array}{r}41.81 \\
(32)\end{array}$ & $\begin{array}{c}42.53 \\
(28)\end{array}$ & $48.39(213)$ & imp. \\
\hline EST & $\begin{array}{c}54.21 \\
\text { (5) }\end{array}$ & $\begin{array}{c}43.09 \\
(6)\end{array}$ & $\begin{array}{c}42.66 \\
(7)\end{array}$ & $\begin{array}{c}39.29 \\
(7)\end{array}$ & $\begin{array}{c}47.54 \\
(7)\end{array}$ & $\begin{array}{c}44.93 \\
(8)\end{array}$ & $\begin{array}{c}55.78 \\
\text { (7) }\end{array}$ & $46.78(47)$ & det. \\
\hline HRV & $\begin{array}{c}60.07 \\
(28)\end{array}$ & $\begin{array}{c}63.07 \\
(30)\end{array}$ & $\begin{array}{c}58.40 \\
(30)\end{array}$ & $\begin{array}{c}58.85 \\
(32)\end{array}$ & $\begin{array}{c}55.07 \\
(34)\end{array}$ & $\begin{array}{c}54.53 \\
(34)\end{array}$ & $\begin{array}{c}54.76 \\
(32)\end{array}$ & $57.82(220)$ & imp. \\
\hline HUN & $\begin{array}{c}55.05 \\
(39)\end{array}$ & $\begin{array}{c}56.45 \\
(36)\end{array}$ & $\begin{array}{c}57.76 \\
(36)\end{array}$ & $\begin{array}{c}64.27 \\
(35)\end{array}$ & $\begin{array}{c}50.20 \\
(34)\end{array}$ & $\begin{array}{c}51.27 \\
(32)\end{array}$ & $\begin{array}{c}52.41 \\
(25)\end{array}$ & 55.35 (237) & imp. \\
\hline LTU & $\begin{array}{c}61.76 \\
(9)\end{array}$ & $\begin{array}{c}55.84 \\
(10)\end{array}$ & $\begin{array}{c}50.16 \\
(10)\end{array}$ & $\begin{array}{c}52.48 \\
(10)\end{array}$ & $\begin{array}{c}60.84 \\
(12)\end{array}$ & $\begin{array}{c}60.08 \\
(12)\end{array}$ & $\begin{array}{c}58.57 \\
(11)\end{array}$ & $57.10(74)$ & imp. \\
\hline LVA & $\begin{array}{c}53.43 \\
(20)\end{array}$ & $\begin{array}{c}52.34 \\
(20)\end{array}$ & $\begin{array}{c}48.73 \\
(20)\end{array}$ & $\begin{array}{c}54.96 \\
(19)\end{array}$ & $\begin{array}{c}53.92 \\
(20)\end{array}$ & $\begin{array}{c}25.72 \\
(21)\end{array}$ & $\begin{array}{c}62.39 \\
(18)\end{array}$ & 50.21 (138) & det. \\
\hline MDA & $\begin{array}{c}55.78 \\
(12)\end{array}$ & $\begin{array}{c}49.71 \\
(11)\end{array}$ & $\begin{array}{c}45.21 \\
(13)\end{array}$ & $\begin{array}{c}50.46 \\
(14)\end{array}$ & $\begin{array}{c}57.69 \\
(13)\end{array}$ & $\begin{array}{c}61.06 \\
(15)\end{array}$ & $\begin{array}{c}56.99 \\
(14)\end{array}$ & $53.84(92)$ & det. \\
\hline
\end{tabular}

(MKD), Romania (ROM) and Serbia (SRB). The EE group includes the four CIS countries: Belarus (BLR), Moldova (MDA), Russia (RUS) and Ukraine (UKR). In order to ensure transparency in tables and graphs three-letter country codes are used.

${ }^{11}$ Bureau van Dijk, BankScope. World Banking Information Source, https://bankscope2.bvdep. com (15.01.2013-28.02.2013).

12 The only exception is Russia, for which a sample of 331 banks of the largest assets has been compiled out of about 1060 banks operating in this country in 2005-2011. The banks not taken into account in the study have about $7 \%$ of the assets in the banking sector of Russia. 


\begin{tabular}{|c|c|c|c|c|c|c|c|c|c|}
\hline \multirow{2}{*}{ Code } & \multicolumn{7}{|c|}{ Years } & \multirow{2}{*}{$\begin{array}{c}\text { Average } \\
\text { (total) }\end{array}$} & \multirow{2}{*}{ Change } \\
\hline & 2005 & 2006 & 2007 & 2008 & 2009 & 2010 & 2011 & & \\
\hline \multicolumn{10}{|c|}{ Countries } \\
\hline MKD & $\begin{array}{c}56.84 \\
(11)\end{array}$ & $\begin{array}{c}58.47 \\
(11)\end{array}$ & $\begin{array}{c}55.06 \\
(14)\end{array}$ & $\begin{array}{c}57.75 \\
(14)\end{array}$ & $\begin{array}{c}63.74 \\
(14)\end{array}$ & $\begin{array}{c}66.13 \\
(14)\end{array}$ & $\begin{array}{c}67.84 \\
(14)\end{array}$ & $60.83(92)$ & det. \\
\hline MNE & $\begin{array}{c}77.96 \\
(8)\end{array}$ & $\begin{array}{c}74.93 \\
(9)\end{array}$ & $\begin{array}{c}59.48 \\
(10)\end{array}$ & $\begin{array}{c}63.11 \\
(9)\end{array}$ & $\begin{array}{c}65.12 \\
(9)\end{array}$ & $\begin{array}{c}62.98 \\
(8)\end{array}$ & $\begin{array}{c}59.27 \\
(8)\end{array}$ & $66.12(61)$ & imp. \\
\hline $\mathrm{POL}$ & $\begin{array}{c}62.81 \\
(36)\end{array}$ & $\begin{array}{c}60.95 \\
(35)\end{array}$ & $\begin{array}{c}56.76 \\
(32)\end{array}$ & $\begin{array}{c}56.11 \\
(38)\end{array}$ & $\begin{array}{c}55.87 \\
(40)\end{array}$ & $\begin{array}{c}53.64 \\
(43)\end{array}$ & $\begin{array}{c}52.61 \\
(40)\end{array}$ & $56.97(264)$ & imp. \\
\hline ROM & $\begin{array}{c}67.29 \\
(27)\end{array}$ & $\begin{array}{c}65.35 \\
(26)\end{array}$ & $\begin{array}{c}61.80 \\
(26)\end{array}$ & $\begin{array}{c}52.94 \\
(29)\end{array}$ & $\begin{array}{r}49.51 \\
(31)\end{array}$ & $\begin{array}{c}50.51 \\
(29)\end{array}$ & $\begin{array}{c}56.36 \\
(27)\end{array}$ & 57.68 (195) & imp. \\
\hline RUS & $\begin{array}{l}50.75 \\
(248)\end{array}$ & $\begin{array}{l}50.63 \\
(300)\end{array}$ & $\begin{array}{l}54.02 \\
(320)\end{array}$ & $\begin{array}{l}53.71 \\
(315)\end{array}$ & $\begin{array}{l}45.40 \\
(337)\end{array}$ & $\begin{array}{l}51.03 \\
(350)\end{array}$ & $\begin{array}{l}55.73 \\
(329)\end{array}$ & $\begin{array}{l}51.61 \\
(2199)\end{array}$ & det. \\
\hline SRB & $\begin{array}{c}62.48 \\
(25)\end{array}$ & $\begin{array}{c}72.89 \\
(27)\end{array}$ & $\begin{array}{c}64.93 \\
(28)\end{array}$ & $\begin{array}{c}81.09 \\
(33)\end{array}$ & $\begin{array}{c}68.34 \\
(36)\end{array}$ & $\begin{array}{c}80.75 \\
(34)\end{array}$ & $\begin{array}{c}65.78 \\
(31)\end{array}$ & $70.89(214)$ & det. \\
\hline SVK & $\begin{array}{c}64.97 \\
(17)\end{array}$ & $\begin{array}{c}58.72 \\
(15)\end{array}$ & $\begin{array}{c}57.09 \\
(19)\end{array}$ & $\begin{array}{c}55.22 \\
(21)\end{array}$ & $\begin{array}{c}58.87 \\
(19)\end{array}$ & $\begin{array}{c}52.35 \\
(16)\end{array}$ & $\begin{array}{c}53.95 \\
(15)\end{array}$ & $57.31(122)$ & imp. \\
\hline SVN & $\begin{array}{c}60.77 \\
(17)\end{array}$ & $\begin{array}{c}61.44 \\
(17)\end{array}$ & $\begin{array}{c}57.06 \\
(17)\end{array}$ & $\begin{array}{c}60.82 \\
(18)\end{array}$ & $\begin{array}{c}58.88 \\
(20)\end{array}$ & $\begin{array}{c}55.20 \\
(20)\end{array}$ & $\begin{array}{c}60.43 \\
(20)\end{array}$ & $59.23(129)$ & imp. \\
\hline UKR & $\begin{array}{c}62.85 \\
(35)\end{array}$ & $\begin{array}{c}58.32 \\
(45)\end{array}$ & $\begin{array}{c}58.69 \\
(47)\end{array}$ & $\begin{array}{c}47.69 \\
(46)\end{array}$ & $\begin{array}{c}52.39 \\
(52)\end{array}$ & $\begin{array}{c}55.86 \\
(55)\end{array}$ & $\begin{array}{c}56.28 \\
(40)\end{array}$ & $56.01(320)$ & imp. \\
\hline \multicolumn{10}{|c|}{ Geographical groups } \\
\hline CESEE & $\begin{array}{l}56.21 \\
(623)\end{array}$ & $\begin{array}{l}55.16 \\
(683)\end{array}$ & $\begin{array}{l}55.00 \\
(719)\end{array}$ & $\begin{array}{l}55.26 \\
(739)\end{array}$ & $\begin{array}{l}48.93 \\
(785)\end{array}$ & $\begin{array}{l}51.33 \\
(803)\end{array}$ & $\begin{array}{l}54.27 \\
(727)\end{array}$ & $\begin{array}{l}53.74 \\
(5079)\end{array}$ & imp. \\
\hline CEB & $\begin{array}{l}58.84 \\
(201)\end{array}$ & $\begin{array}{l}57.80 \\
(196)\end{array}$ & $\begin{array}{l}55.35 \\
(200)\end{array}$ & $\begin{array}{l}56.83 \\
(212)\end{array}$ & $\begin{array}{l}51.54 \\
(221)\end{array}$ & $\begin{array}{l}50.02 \\
(218)\end{array}$ & $\begin{array}{l}51.46 \\
(196)\end{array}$ & $\begin{array}{c}54.55 \\
(1444)\end{array}$ & imp. \\
\hline SEE & $\begin{array}{l}55.23 \\
(118)\end{array}$ & $\begin{array}{l}57.51 \\
(121)\end{array}$ & $\begin{array}{l}54.83 \\
(125)\end{array}$ & $\begin{array}{l}57.15 \\
(136)\end{array}$ & $\begin{array}{l}53.08 \\
(144)\end{array}$ & $\begin{array}{l}55.23 \\
(144)\end{array}$ & $\begin{array}{l}56.20 \\
(135)\end{array}$ & $55.60(923)$ & det. \\
\hline $\mathrm{EE}$ & $\begin{array}{l}52.44 \\
(304)\end{array}$ & $\begin{array}{l}51.63 \\
(366)\end{array}$ & $\begin{array}{l}54.68 \\
(394)\end{array}$ & $\begin{array}{l}53.37 \\
(391)\end{array}$ & $\begin{array}{l}46.15 \\
(420)\end{array}$ & $\begin{array}{l}51.50 \\
(441)\end{array}$ & $\begin{array}{l}55.60 \\
(396)\end{array}$ & $\begin{array}{l}52.20 \\
(2712)\end{array}$ & det. \\
\hline
\end{tabular}

Information: the weight is the share of a given bank in the interest income of banks in a given country; the number of observations (banks) is given in brackets; det. (imp.) - deterioration (improvement) of cost efficiency, i.e. increase (decrease) of $C /$.

Source: Own preparation based on BankScope data.

The analysis of table 1 leads to the following conclusions. On average, the most cost efficient banks are the banks in Bulgaria, Estonia, the Czech Republic and Latvia. At the same time, on average the least cost efficient are banks in Bosnia and Herzegovina, Montenegro and Serbia. The cost efficiency of banks in the CESEE countries is very varied. The cost-to-income ratio ranges from $38.57 \%$ in Bulgaria to 70.89\% in Serbia. On average, in all of the analyzed countries the $C / I$ ratio equals $53.74 \%$. 
The (operating) cost to (operating) income ratio is a financial measure, especially important for the evaluation of the operation of banks. It allows testing the operating efficiency of a bank - the lower the value of the $C / I$ ratio the higher the profitability of the bank. As it is evidenced in the works of S.N. Ghosh, D.M. Narain and S. Sahoo ${ }^{13}$ and K. Hess and G. Francis ${ }^{14}$, banks which are more cost efficient generate more significant profits. Moreover, the increase in the value of the ratio means that the costs grow faster or decrease slower than the income.

In the study the distance from the pattern method was applied. This method, being a way of the linear ordering of a set of objects, is based on synthetic variables in relation to which the pattern is determined, i.e. the model object of desirable features. According to T. Panek „in pattern methods we assume the existence of a model object in which input variables assume optimum values. The values of input variables for the model object may be set on the basis of generally accepted standards, opinions of experts and on the basis of observation of their values in ordered objects" ${ }^{15}$.

Calculating the distance of selected indicators we need to select the pattern, in this case a bank, which meets certain requirements. It is possible to use a virtual bank which combines the highest possible values of indexes or a bank which combines the best real value of indexes or a bank (or a group of banks) recording on average the best value of indicators.

For the purpose of this study, the adopted pattern is the lowest value of the $C / I$ ratio achieved by a model bank in a given country. Then, by the author's subjective decision, it was assumed that the bank is cost efficient if the $C / I$ ratio is lower or equal to 1.2 of the ratio recorded by the model bank. Next, the percentage of cost inefficient banks was calculated $(C / I>1.2)$.

13 S.N. Ghosh, D.M. Narain, S. Sahoo, Capital Requirements and Bank Behaviour: An Empirical Analysis of Indian Public Sector Banks, "Journal of International Development", Vol. 15, No. 2/2003.

${ }^{14}$ K. Hess, G. Francis, Cost Income Ratio Benchmarking in Banking: A Case Study, „Benchmarking: An International Journal", Vol. 11, No. 3/2004.

${ }_{15}$ Panek T., Statystyczne metody wielowymiarowej analizy porównawczej, Oficyna Wydawnicza SGH, Warszawa 2009, p. 58. 


\section{RESULTS}

The values of the cost-to-income ratio indicate relatively significant inefficiency of banking sectors in the CESEE countries. This is evidenced by the variation of the $C / I$ ratio (measured with the use of the distance from the pattern method), a high percentage of cost inefficient banks and the changes in the cost-to-income ratio.

It was assumed that the cost efficiency pattern in a given country is the bank generating a given level of profit with the lowest cost. Next, the distance from the pattern was calculated, with the assumption that the minimum value of $C / I$ is 1 . Because banking sectors of the CESEE countries differ considerably when it comes to the number of banks (see: table 1), the average distance of the $C / I$ ratio from the pattern was calculated. The smallest variation of cost efficiency measured with the average distance of the ratio from the pattern is characteristic for the banking sectors of the following countries: Montenegro, Lithuania, Belarus, Bosnia and Herzegovina and Slovakia. In these countries, the calculated average distance from the pattern does not exceed one. At the same time, the banking sectors in Bulgaria, Hungary, Ukraine and Russia are characterized by strong differentiation of cost-effectiveness. In these countries, banks are three times less cost effective than the bank of the lowest cost-to-income ratio. The values of the distance from the $C / I$ pattern for particular countries of the CESEE and their geographical groups are presented in table 2 .

Table 2. Average distance from the cost-to-income ratio pattern

\begin{tabular}{|c|c|c|c|c|c|c|c|c|c|c|}
\hline \multirow{2}{*}{ CODE } & \multicolumn{7}{|c|}{ YEARS } & \multirow{2}{*}{ AVERAGE } & \multirow{2}{*}{ POSITION } \\
\cline { 2 - 9 } & 2005 & 2006 & 2007 & 2008 & 2009 & 2010 & 2011 & & \\
\hline ALB & 0.31 & 1.62 & 1.02 & 0.70 & 1.20 & 1.60 & 1.18 & 1.09 & 7 \\
\hline BGR & 1.90 & 2.40 & 2.57 & 4.52 & 2.72 & 3.27 & 3.94 & 3.05 & 17 \\
\hline B\&H & 0.55 & 1.08 & 0.83 & 0.64 & 0.67 & 1.20 & 0.75 & 0.82 & 4 \\
\hline BLR & 0.21 & 0.42 & 1.54 & 0.59 & 0.80 & 0.48 & 1.41 & 0.78 & 3 \\
\hline CZE & 1.85 & 1.94 & 1.76 & 2.56 & 2.93 & 2.93 & 2.64 & 2.37 & 14 \\
\hline EST & 0.89 & 1.23 & 0.53 & 0.88 & 1.23 & 1.01 & 1.81 & 1.08 & 6 \\
\hline HRV & 1.03 & 1.71 & 1.38 & 4.08 & 4.86 & 4.21 & 2.03 & 2.76 & 15 \\
\hline HUN & 1.44 & 2.00 & 2.25 & 3.40 & 2.99 & 2.14 & 7.67 & 3.13 & 18 \\
\hline
\end{tabular}




\begin{tabular}{|c|c|c|c|c|c|c|c|c|c|}
\hline \multirow{2}{*}{ CODE } & \multicolumn{7}{|c|}{ YEARS } & \multirow{2}{*}{ AVERAGE } & \multirow{2}{*}{ POSITION } \\
\hline & 2005 & 2006 & 2007 & 2008 & 2009 & 2010 & 2011 & & \\
\hline \multicolumn{10}{|c|}{ Countries } \\
\hline LTU & 0.26 & 0.41 & 0.66 & 0.62 & 1.02 & 0.91 & 1.10 & 0.71 & 2 \\
\hline LVA & 1.21 & 3.16 & 2.62 & 3.41 & 0.73 & 1.72 & 0.80 & 1.95 & 13 \\
\hline MDA & 2.80 & 0.97 & 0.92 & 1.58 & 1.29 & 0.86 & 1.14 & 1.37 & 9 \\
\hline MKD & 0.75 & 0.99 & 1.19 & 2.09 & 1.22 & 1.85 & 1.96 & 1.44 & 10 \\
\hline MNE & 0.28 & 0.58 & 0.30 & 0.54 & 0.42 & 0.25 & 0.49 & 0.41 & 1 \\
\hline POL & 1.88 & 2.36 & 1.03 & 0.84 & 1.61 & 1.40 & 3.35 & 1.78 & 11 \\
\hline ROM & 1.99 & 0.66 & 0.65 & 1.06 & 1.76 & 1.74 & 1.22 & 1.30 & 8 \\
\hline RUS & 10.28 & 4.81 & 3.75 & 6.56 & 8.42 & 10.09 & 3.29 & 6.74 & 20 \\
\hline SRB & 1.39 & 1.41 & 2.02 & 4.36 & 1.91 & 0.96 & 1.00 & 1.86 & 12 \\
\hline SVK & 0.48 & 0.61 & 1.02 & 1.23 & 1.36 & 0.85 & 0.55 & 0.87 & 5 \\
\hline SVN & 3.03 & 1.17 & 1.43 & 1.27 & 1.81 & 9.33 & 2.50 & 2.94 & 16 \\
\hline UKR & 1.10 & 2.89 & 1.27 & 4.18 & 5.52 & 6.24 & 2.79 & 3.43 & 19 \\
\hline \multicolumn{10}{|c|}{ Geographical groups } \\
\hline CESEE & 4.34 & 2.94 & 2.37 & 4.05 & 5.20 & 6.02 & 3.18 & 4.01 & - \\
\hline CEB & 1.61 & 1.89 & 1.57 & 2.10 & 2.41 & 2.50 & 3.53 & 2.23 & - \\
\hline SEE & 1.68 & 1.19 & 1.32 & 2.38 & 1.89 & 1.92 & 1.78 & 1.74 & - \\
\hline $\mathrm{EE}$ & 9.22 & 4.53 & 3.45 & 6.22 & 7.94 & 9.20 & 3.21 & 6.25 & - \\
\hline
\end{tabular}

Source: Own preparation based on BankScope data.

Next, it was assumed that a bank is cost effective if the $C / I$ ratio does not exceed $120 \%$ of the value determined by the model bank. This means that banks whose $C / I$ exceeds $120 \%$ of the pattern value were considered cost inefficient. According to this definition, over 95\% banks in the CESEE countries are cost inefficient. There are however significant differences between particular countries. In countries such as Montenegro, Albania or Estonia, the level of cost inefficiency is relatively low and concerns 56.69 and $71 \%$ of banks respectively. At the same time, in Russia, the share of cost inefficient banks is $99.5 \%$. table 3 presents the percentage of cost inefficient banks in particular CESEE countries and their geographical groups. 
Table 3. Percentage of banks with cost inefficiency at the level exceeding $120 \%$ of the pattern value

\begin{tabular}{|c|c|c|c|c|c|c|c|c|c|}
\hline \multirow{2}{*}{ CODE } & \multicolumn{7}{|c|}{ YEARS } & \multirow{2}{*}{ AVERAGE } & \multirow{2}{*}{ POSITION } \\
\hline & 2005 & 2006 & 2007 & 2008 & 2009 & 2010 & 2011 & & \\
\hline \multicolumn{10}{|c|}{ Countries } \\
\hline$A L B$ & 0.200 & 0.571 & 0.625 & 0.857 & 0.889 & 0.909 & 0.778 & 0.690 & 2 \\
\hline$B G R$ & 0.958 & 0.958 & 0.947 & 0.958 & 0.920 & 0.960 & 0.958 & 0.952 & 16 \\
\hline$B \& H$ & 0.944 & 0.941 & 0.950 & 0.950 & 0.900 & 0.957 & 0.909 & 0.936 & 13 \\
\hline BLR & 0.333 & 0.800 & 0.929 & 0.938 & 0.833 & 0.714 & 0.769 & 0.759 & 5 \\
\hline CZE & 0.933 & 0.963 & 0.931 & 0.969 & 0.943 & 0.938 & 0.964 & 0.949 & 15 \\
\hline EST & 0.800 & 0.833 & 0.571 & 0.571 & 0.714 & 0.625 & 0.857 & 0.710 & 3 \\
\hline HRV & 0.964 & 0.967 & 0.967 & 0.969 & 0.971 & 0.971 & 0.969 & 0.968 & 19 \\
\hline HUN & 0.949 & 0.972 & 0.944 & 0.971 & 0.971 & 0.938 & 0.960 & 0.958 & 17 \\
\hline LTU & 0.556 & 0.700 & 0.800 & 0.800 & 0.750 & 0.833 & 0.636 & 0.725 & 4 \\
\hline LVA & 0.950 & 0.950 & 0.950 & 0.947 & 0.800 & 0.857 & 0.722 & 0.882 & 8 \\
\hline MDA & 0.917 & 0.818 & 0.846 & 0.857 & 0.923 & 0.867 & 0.929 & 0.879 & 7 \\
\hline MKD & 0.727 & 0.909 & 0.929 & 0.929 & 0.857 & 0.929 & 0.929 & 0.887 & 9 \\
\hline MNE & 0.500 & 0.444 & 0.600 & 0.556 & 0.556 & 0.500 & 0.750 & 0.558 & 1 \\
\hline POL & 0.944 & 0.971 & 0.875 & 0.816 & 0.975 & 0.953 & 0.975 & 0.930 & 12 \\
\hline ROM & 0.963 & 0.846 & 0.846 & 0.793 & 0.903 & 0.966 & 0.778 & 0.871 & 6 \\
\hline RUS & 0.992 & 0.997 & 0.997 & 0.997 & 0.994 & 0.997 & 0.991 & 0.995 & 20 \\
\hline SRB & 0.920 & 0.889 & 0.964 & 0.970 & 0.972 & 0.882 & 0.871 & 0.924 & 11 \\
\hline SVK & 0.824 & 0.933 & 0.947 & 0.952 & 0.947 & 0.875 & 0.733 & 0.887 & 10 \\
\hline SVN & 0.941 & 0.941 & 0.941 & 0.944 & 0.950 & 0.950 & 0.950 & 0.945 & 14 \\
\hline UKR & 0.914 & 0.978 & 0.957 & 0.978 & 0.981 & 0.982 & 0.975 & 0.966 & 18 \\
\hline \multicolumn{10}{|c|}{ Geographical groups } \\
\hline CESEE & 0.939 & 0.961 & 0.945 & 0.940 & 0.964 & 0.958 & 0.956 & 0.952 & - \\
\hline CEB & 0.925 & 0.954 & 0.916 & 0.900 & 0.946 & 0.929 & 0.934 & 0.929 & - \\
\hline SEE & 0.918 & 0.871 & 0.880 & 0.870 & 0.908 & 0.942 & 0.843 & 0.890 & - \\
\hline $\mathrm{EE}$ & 0.964 & 0.990 & 0.991 & 0.993 & 0.989 & 0.980 & 0.986 & 0.985 & - \\
\hline
\end{tabular}

Source: Own preparation based on BankScope data. 
On average, the cost efficiency of banks in the CESEE countries has improved in the analyzed period (see table 1). The improvement is mostly the result of reducing the cost-to-income ratio in banks in the CEB countries ${ }^{16}$. In the case of other geographical groups, the cost-to-income ratio has deteriorated. From among twenty CESEE countries, in eight of them: Bulgaria, Bosnia and Herzegovina, Estonia, Latvia, Macedonia, Moldova, Russia, and Serbia the $C / I$ ratio has worsened.

The estimated level of cost inefficiency of banks in the CESEE countries indicates that they operate on a market which is far from the perfect competition structure. The lack of sufficient competition pressure results in a situation in which the profit maximization is not a precondition for the banks' survival on the market and in imperfectly competitive structures (monopolistic competition, oligopoly) there is a lot of space for inefficiency and exploitation of market power.

\section{DISCUSSION}

In the relevant literature there is no consensus as to what the sources of discrepancies in the efficiency of banks are. The lack of banking efficiency (including cost efficiency) may be potentially caused by: differences in efficiency measuring, the number of banks in the sector, the competitive structure of the banking services market and the regulation of the operation of banking sectors ${ }^{17}$. This article concentrates on the competitive structure of the banking services market as a source of banks' cost inefficiency.

Research into the cost efficiency of banks in mature market economies reveals inefficiency at the level of $20 \%$. This means that $80 \%$ of these banks are as cost effective as the pattern. Inefficiency with respect to profit is higher and reaches even 50\%. The overview of literature devoted to the efficiency of the American banking sector can be found in the work of A.N. Berger and L. Mester ${ }^{18}$. The results presented in the previous section indicate that the inefficiency of banks in the analyzed transition countries is much higher than in developed market economies.

In order to analyze the co-dependency of the cost efficiency of banks and the factors characterizing the competition structure of the banking services sector, the correlation ratio was calculated, contrasting the weighted av-

\footnotetext{
${ }_{16}$ The exceptions are Estonia and Latvia.

17 A.N. Berger, L. Mester, op. cit., p. 896.

18 Ibidem, p. 896.
} 
erage value of $C / I$, the distance from the banking efficiency pattern and the percentage of ineffective banks with such variables as: the concentration of the banking sector measured by the share of the five largest suppliers in the market $\left(C E_{5}\right)$ and the Herfindahl-Hirschman Index (HHI), the number of banks $(N$, logarithmized in order to scale the variable), competition in the banking market (measured by the $\mathrm{H}$ statistic in two variants of the $\mathrm{P}-\mathrm{R}$ model) ${ }^{19}$. The correlation coefficient between these values in presented in table 4.

Table 4. Interdependence of the cost efficiency of banks and the number of banks, concentration and competition

\begin{tabular}{|l|c|c|c|c|c|}
\hline \multicolumn{1}{|c|}{ CORRELATION: } & $\mathrm{CR}_{5}$ & $\mathrm{HHI}$ & $\mathrm{H}_{1}$ & $\mathrm{H}_{2}$ & LOG N \\
\hline weighted average C// with: & $-0,09$ & $-0,20$ & $-0,01$ & 0,07 & $-0,08$ \\
\hline average distance of C// from the pattern with: & $-0,63$ & $-0,38$ & $-0,31$ & $-0,34$ & 0,88 \\
\hline $\begin{array}{l}\text { percentage of banks with cost inefficiency at the level } \\
\text { higher than 120\% of the pattern value with: }\end{array}$ & $-0,78$ & $-0,63$ & $-0,56$ & $-0,63$ & 0,73 \\
\hline
\end{tabular}

Information: Italics indicate the correlation coefficients for which there is no basis to reject the hypothesis of their zero value at the significance level equalling 0.05 .

Source: Own preparation based on BankScope data.

Before analyzing the interdependence of cost efficiency of banks and their competition structure it was assumed that the relation between these values will be in accordance with the theory of microeconomics. According to this theory, the cost efficiency of banks should be the higher, (1) the lower the level of the concentration of the banking sector, (2) the higher the level of competition in the banking services market and (3) the greater the number of banks. The obtained concentration values contradict at least some of the findings of the theory of economics.

The correlation of the average weighted cost-to-income ratio and the indicators of competition is not significantly different from zero, which indicates that there is no interdependency of these variables. At the same time, the measures of the cost inefficiency of banks such as the distance of $C / I$ from the pattern or the percentage of inefficient banks show a certain level of interdependency with factors determining the level of competition. The higher concentration of the banking sector (measured by both $C R_{5}$ and HHI) is accompanied by a lover percentage of cost inefficient banks and a smaller distance

19 The concentration and competition ratios were calculated on the basis of the panel of data covering the same space and time range as in the study of the cost efficiency of banks. Due to the limitations concerning the size of the article in the journal, the values of the concentration and competition ratios were not given. 
of the cost-to-income coefficient from the pattern (negative correlation coefficients in table 4). This observation is confirmed by the correlation coefficients of the cost inefficiency of banks with a number of banks. More numerous banking sectors (which usually also means less concentrated banking sectors ${ }^{20}$ ) are characterized by a higher level of banks' cost inefficiency (positive correlation coefficients in table 4). These results are surprising from the perspective of the traditional approach to the industrial economics, known as the Structure-Conduct-Performance (SCP) Paradigm, but in the light of contemporary findings (e.g. New Empirical Industrial Organization (NEIO)) it is possible to explain them. Because the freedom of entry into the banking services market leads to an excessive number of banks ${ }^{21}$, this results in a market equilibrium, which is not a socially optimum solution, as it is accompanied by the phenomenon of inefficiency, including cost inefficiency ${ }^{22}$. Therefore, the result of examining the interaction of variables indicates an increase in inefficiency as the number of suppliers in the banking services market grows. At the same time, the coexistence of high concentration with a low level of inefficiency means that banks maximize economies of scale to optimize efficiency.

In line with the expectations, however, is the correlation coefficient of the cost inefficiency of banks and the indicators of competition. The negative value of the correlation coefficient (see: table 4) indicates that higher banks' cost inefficiency is observable in those banking sectors in which the level of competition (measured with the use of the $H$ statistics by Panzar and Rosse) is lower. This means than on less competitive banking services markets the level of cost inefficiency of banks is higher, which results from lower competitive pressure.

\section{CONCLUSIONS}

Analyzing the cost-to-income ratio in banks in the CESEE countries shows that their inefficiency is relatively significant. The present article provides evidence for $\mathrm{X}$-inefficiency in the banking sectors of European transi-

${ }^{20}$ It must be also remembered that the level of concentration of the sector depends on the number of suppliers in the market and on the distribution of their size. Each of the factors alone does not determine the ultimate level of concentration.

${ }^{21}$ X. Freixas, J.Ch. Rochet, Mikroekonomia bankowa, CeDeWu, Warszawa 2008, p. 48.

22 The proof for the existence of a non-optimal number of banks as a source of inefficiency is found in the work of A. Baszyński, Koncentracja i konkurencja w sektorach bankowych transformujących się krajów europejskich. Studium teoretyczno-empiryczne, Wydawnictwo Uniwersytetu Ekonomicznego w Poznaniu, Poznań 2014, p. 88-90. 
tion countries. In the case of $95.2 \%$ of banks the costs of producing a banking service by a given bank is greater than the possible lowest cost of producing this service. The average distance of the $C / I$ ratio from the pattern is 4 and is the most significant in the EE group of countries (6.25) and the least significant in the SEE group (1.74). The CEB countries are characterized by a moderate distance from the pattern, equalling 2.23.

Research into competition in the banking services market ${ }^{23}$ points at the existence of monopolistic competition in most banking sectors in analyzed countries. On the one hand, the level of cost inefficiency of banks is so high that it calls into question the theory of the existence of monopolistic competition as the dominant competitive structure of the banking market. On the other hand, if the level of the inefficiency of suppliers in the market is influenced by factors other than the level of competition, the coexistence of high inefficiency and competition is possible. Still, the falsification of this hypothesis requires further research.

\section{BIBLIOGRAPHY}

Anzoategui D., Martínez Pería M.S., Rocha R., Bank Competition in the Middle East and Northern Africa Region, „World Bank Policy Research Working Paper”, No. 5363/2010, http://dx.doi.org/10.1596/1813-9450-5363.

Bain J.S., Barriers to New Competition: Their Character and Consequences in Manufacturing Industries, Harvard University Press, Cambridge 1956.

Baszyński A., Koncentracja i konkurencja w sektorach bankowych transformujacych sie krajów europejskich. Studium teoretyczno-empiryczne, Wydawnictwo Uniwersytetu Ekonomicznego w Poznaniu, Poznań 2014.

Berger A.N., Mester L., Inside the Black Box: What Explains Differences in the Efficiencies of Financial Institutions?, "Journal of Banking and Finance", Vol. 21, No. 7/1997, http://dx.doi.org/10.1016/S0378-4266(97)00010-1.

Bikker J.A., Spierdijk L., How Banking Competition Changed over Time?, DNB Working Papers, No. 167/2008, De Nederlndsche Bank, Amsterdam 2008.

Bureau van Dijk, BankScope. World Banking Information Source, https://bankscope2. bvdep.com (15.01.2013-28.02.2013).

Claessens S., Laeven L., What Drives Bank Competition? Some International Evidence, „Journal of Money, Credit and Banking”, Vol. 36, No. 3/2004, http://dx.doi. org/10.1353/mcb.2004.0044.

${ }^{23}$ Among other works: M.D. Delis, op. cit. 
Delis M.D., Competitive Conditions in the Central and Eastern European Banking Systems, „Omega”, Vol. 38, No. 5/2010, http://dx.doi.org/10.1016/j.omega.2008.09.002.

Drakos K., Konstantinou P., Competition and Contestability in Transition Banking: An Empirical Analysis, „South-Eastern Europe Journal of Economics”, Vol. 3, No. 2/2005.

ECB, Statistical Data Warehouse. Structural Financial Indicators, http://sdw.ecb.europa.eu (19.03.2013).

Freixas X., Rochet J.Ch., Mikroekonomia bankowa, CeDeWu, Warszawa 2008.

Gelos G.R., Roldos J., Consolidation and Market Structure in Emerging Market Banking Systems, „IMF Working Paper”, No. 186/2002, http://dx.doi.org/10.2139/ ssrn.352061.

Ghosh S.N., Narain D.M., Sahoo S., Capital Requirements and Bank Behaviour: An Empirical Analysis of Indian Public Sector Banks, „Journal of International Development", Vol. 15, No. 2/2003, http://dx.doi.org/10.1002/jid.947.

Hess K., Francis G., Cost Income Ratio Benchmarking in Banking: A Case Study, „Benchmarking: An International Journal”, Vol. 11, No. 3/2004, http://dx.doi. org/10.1108/14635770410538772.

Holló D., Nagy M., Bank Efficiency in the Enlarged European Union, MNB Working Papers, No. 3/2006, MNB, Budapest 2006.

Koutsomanoli-Fillipaki N., Staikouras Ch., Competition and Concentration in the Nerw European Banking Landscape, „European Financial Management”, Vol. 12, No. 3/2006, http://dx.doi.org/10.1111/j.1354-7798.2006.00327.x.

Leibenstein H., Allocative Efficiency vs. X-Efficiency, „American Economic Review”, Vol. 56, No. 3/1966. (http://www.jstor.org/stable/1823775).

Lerner A.P., The Concept of Monopoly and the Measurement of Monopoly Power, „Review of Economic Studies", Vol. 1, No. 3/1934, http://dx.doi.org/10.2307/2967480.

Mamatzakis E., Staikouras C., Koutsomanoli-Fillipaki N., Competition and Concentration in the Banking Sector of the South Eastern European Region, „Emerging Markets Review", Vol. 6, No. 2/2005, http://dx.doi.org/10.1016/j.ememar.2005.03.003.

Mason E.S., Price and Production Policies of Large-scale Enterprises, „American Economic Review", Vol. 29, No. 1/1939.

Mkrtchyan A., The Evolution of Competition in Banking in a Transition Economy: An Application of the Panzar-Rosse Model to Armenia, „European Journal of Comparative Economics", Vol. 2, No. 1/2005.

Northcott C.A., Competition in Banking: A Review of the Literature, Bank of Canada Working Paper, No. 24/2004, Bank of Canada, Ottawa 2004.

Note S., Competition in the Albanian Banking System, Bank of Albania Working Paper, Tirana 2007.

Panek T., Statystyczne metody wielowymiarowej analizy porównawczej, Oficyna Wydawnicza SGH, Warszawa 2009. 
Pawłowska M., Competition, Concentration, Efficiency, and their Relationship in the Polish Banking Sector, „Materiały i Studia”, No. 32/2005, NBP, Warszawa 2005.

Pawłowska M., Konkurencja na polskim rynku bankowym na tle zmian strukturalnych i technologicznych - wyniki empiryczne, [in:] E. Miklaszewska (ed.), Bank na rynku finansowym. Problemy skali, efektywności i nadzoru, Oficyna a Wolters Kluwer business, Warszawa 2010.

Utmelidze A., Banking Competition: The Case of Georgia and Belarus, http://kse.org.ua/ uploads/file/library/2007/utmelidze_2007.doc (12.06.2013).

Yildirim H.S., Philippatos G.C., Competition and Contestability in Central and Eastern European Banking Markets, „Managerial Finance”, Vol. 33, No. 3/2007, http:// dx.doi.org/10.1108/03074350710718275. 